\title{
EFFECTS OF LESS FAVOURED AREAS SUPPORT IN TERRITORIES WITH NATURAL CONSTRAINTS
}

\author{
Y. Kazakova-Mateva* \\ Economics of Natural Resources Department, University of National and World Economy, \\ Sofia, Bulgaria
}

\begin{abstract}
The paper aims to assess the effects of the support provided to areas with natural constraints in the framework of the measure under the Rural Development Programmes in Bulgaria since 2007. The importance of the issue is underlined by the requirement of the European Commission for member states to review the designation of the former non-mountainous less-favoured areas at latest by end 2017 and to suggest new schemes as of 2018. The objectives of the measure in Bulgaria relate to maintaining the agricultural activity and preventing land abandonment and depopulation; maintaining the landscape and biodiversity as well as promoting the rational use and sustainable management of land and other natural resources. The analysis is based on official implementation data at administrative district and municipal levels for Plovdiv region and overlaying geo-referenced data to enable the assessment of the potential effects on biodiversity and landscape. The relevance of the effects to the set objectives is discussed and recommendations for the 2017 review are developed on this basis.
\end{abstract}

Key words: natural constraints, policy effects, policy review, RDP 2014-2020

\section{INTRODUCTION}

The European policy for supporting mountainous and other less-favoured areas (LFAs) was introduced in 1975. Since then, the designated non-mountainous areas with natural handicaps have been increasing continuously. The European Court of Auditors review of the LFAs support in 2003 found that the "Commission has insufficient evidence that the classification of the LFAs is valid...Monitoring of the LFA scheme is poor due to a lack of relevant data; information from Member States is late or incomplete" (Court of Auditors, 2003). Based on this report, the European Commission initiated a review of the non-mountainous LFAs. In the 2007-2013 programming period, that followed the Court of Auditors report, the target areas were rebranded to "areas facing natural handicaps" and the aim for addressing rural depopulation was taken out (Regulation 1698/2005). In the current programming period, the areas are renamed again to "areas with significant natural constraints" to indicate that the less-favoured criteria are now exclusively focused on natural,

\footnotetext{
*Correspondence to: Yanka Kazakova-Mateva, Economics of Natural Resources Department, University of National and World Economy, Sofia, Bulgaria, tel: 00359-2-8195324, e.mail: yanka.kazakova@gmail.com
}

bio-physical criteria (Regulation 1305/2013). Member States are encouraged to apply the new set of criteria as suggested by the Commission and to designate the areas with natural constraints together with the adoption of the national Rural Development Programmes (RDPs) for the 2014-2020 period. Alternatively, they can use the old designated areas but only till the end of 2017. In the 2018 support year, Member States have to use the areas designated under the new criteria, or digressive support shall be provided to the "old" areas. (DG Agri, 2016).

Bulgaria began the implementation of support to less-favoured areas after the accession to the EU in 2007, when the review of the designation criteria was already ongoing. Thus, the non-mountainous areas with natural handicaps were designated only based on biophysical criteria of poor soil productivity (Ordinance 12008). Bulgaria is among the countries that postponed the re-designation of the areas with significant natural constraints to 2017 as opposed to 2014 when Regulation $1305 / 2013$ entered into force and the RDP 2014-2020 was approved. However, Bulgaria's level of preparedness for redesignation in 2016 is still in "early technical discussions" (JRC, 2016). If the process is not accelerated and finalized by the end of 2017 , 
the farmers in these areas will receive decreased payments as of 2018 .

The paper aims to assess the effects of the support provided to areas with natural constraints in the framework of the measure under the Rural Development Programmes since 2007 and to draw lessons learned for the re-designation process and the targeting of the new support.

\section{MATERIALS AND METHODS}

The research method used is a combination of descriptive analysis of implementation data for the measure supporting areas with significant natural constraints in Plovdiv district; with a desk-based review of the legal and policy framework; and geo-representation (visualization) and overlaying of the designated areas with natural constraints and Natura 2000 areas.

The data used for the analysis is multi-sectoral:

(1) RDP implementation data for the period 2014-2016 - as the years for which data is available in the online system of State Fund Agriculture;

(2) Information from the Land Parcel Identification System for the land use and land eligibility in the studied region available online from the Ministry of Agriculture;

(3) Information on the population in the settlements from Plovdiv district designated as areas with natural constraints - available online from GRAO (Civil Registration and Administrative Service directorate) for the first, mid-, and final years of the programming periods in the study -2007 , 2010, 2013, 2014, 2017 (by June 2017).

(4) Geo-referenced data for the boundaries of Natura 2000 zones from the Ministry of Environment and Water (available online), which are overlaid with the boundaries of the settlements designated as areas with natural constraints. The overlay function is important for identifying the potential of the designated areas to contribute to biodiversity and landscape conservation.

\section{RESULTS AND DISCUSSION \\ The policy and legal framework for LFAs support in Bulgaria}

The mountainous and non-mountainous lessfavoured areas in Bulgaria are designated in 2008 with an Ordinance adopted with a Council of Ministers Decision No.30/15.02.2008. The criteria used for the mountainous LFAs comprise an average altitude above 700 m.a.s.l. and a terrain slope of minimum $20 \%$, or a combination of altitude above 500 m.a.s.l. and a terrain slope of minimum $15 \%$. The criterion used for the nonmountainous areas with natural handicaps is low productivity agricultural land. The number of settlements (LAU2 level) designated as mountainous areas is 1760 (Annex 1 to the Ordinance), while the number of settlements with other natural handicaps is 558 (Annex 2 to the Ordinance). The re-designation requirement applies to the 558 settlements only.

The support objectives for both types of LFAs remain unchanged since 2007. They are set with Ordinance 11/3 April 2008 and are continued by Ordinance 6/24.02.2015. The support under the measure aims to contribute to achieving the following aims:

1) Maintaining the agricultural activity in less favoured areas and preventing the abandonment of agricultural land;

2) Counteract on the depopulation of less favoured areas;

3) Maintaining the landscape and biodiversity;

4) Rational use, conservation and sustainable management of the land and other natural resources.

The review of the support objectives in Bulgaria immediately reveals an inconsistency between the social objectives of addressing depopulation. It was dropped out of the EUlevel objectives with the adoption of Regulation 1698/2005, but still the European Commission approve it in the Bulgarian RDP for two consecutive programming periods 2007-2013 and 2014-2020.

\section{Less-favoured areas in Plovdiv district}

The less-favoured areas in Plovdiv district are dominated by the mountainous areas, which cover the area of 65 settlements (Figure 1). The areas with natural handicaps/constraints cover 22 settlements, and the areas with no natural constraints are 141 .

\section{Beneficiaries of the LFA support in areas with natural constraints in Plovdiv district}

The measure for support in areas with natural handicaps is coded as 212 in the 2007-2013 programming period and as 13.2 in the 20142020 period. The paper refers to the respective codes to indicate the proper programming period.

The implementation of measure 212 in Plovdiv district starts in 2007 with 487 beneficiaries, who increase to 503 in 2009 (Figure 2). The support under measure 212 ends in 2015 with 169 beneficiaries. The new measure 13.2 starts in 2016 with 335 beneficiaries. Overall, there 
is a one-third decrease in the number of beneficiaries between the two programming periods, if we consider the third years in the implementation, which score the highest number of beneficiaries (2009 and 2916 respectively).
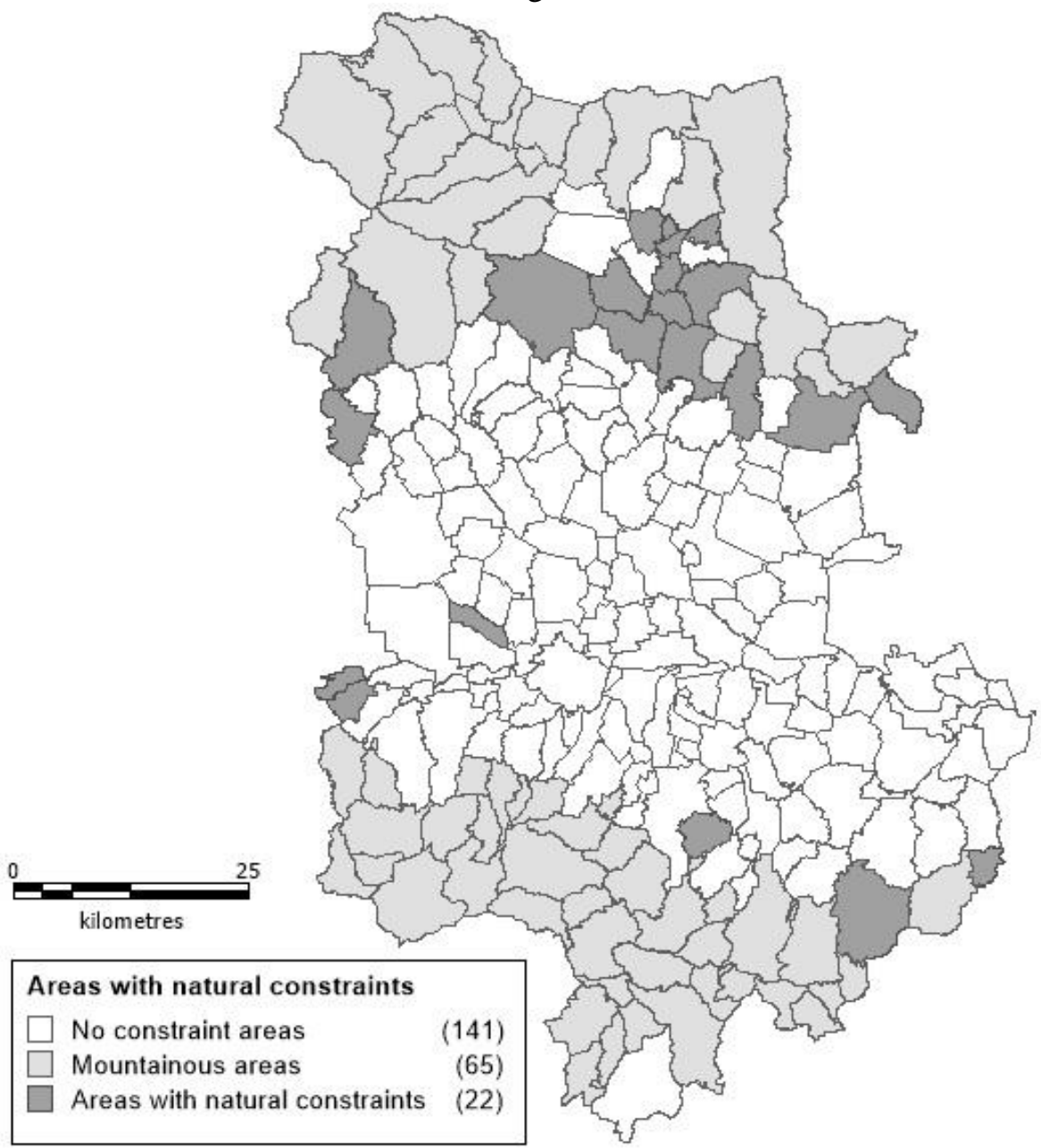

Figure 1. Less-favoured areas in Plovdiv district

Source: Own calculation/presentation based on Council of Ministers Decision No.30/15.02.2008

The analysis of the supported farms according to their farm size is based on a proxy indicator. It considers that the support amount received by the beneficiary reflects exactly its farm size. However, there may be cases where certain reductions are imposed on the support amount, so conclusions on farm size are taken with care.

Four categories of farm sizes are considered: (1) from 1 ha to 5 ha, where 1 ha is the minimum farm size for support under measure 212; and 5 ha is the maximum size for small farms in the EU according to the EU Agricultural Economic Brief on small farms (9). The other three categories are based on the thresholds where the support amount gets digressive: up to 50 ha - the maximum support of $70 \mathrm{Eur} / \mathrm{ha}$ is provided; for the areas above 50 ha up to 100 ha the support is $50 \mathrm{Eur} / \mathrm{ha}$; and for the areas above 100 ha - the support is decreased to 15 Eur/ha.
The biggest group of supported farms is small farms but their share in the overall number of supported farms decreases continuously. They are $64 \%$ of all supported farms in 2007, and fall down to $51 \%$ in 2016. Meanwhile, in 2014-2015 the published data shows no support paid to this category.

The other category, which has a decreasing share in total supported farms, is the farms over 100 ha. They are $7 \%$ in 2007 , and fall down to $5 \%$ in 2016 . The farm size category with increasing number of farms, and an increasing share is the 50-100 ha farm size group. There are 21 farms in 2007 (4\% of all) and are up to 39 farms (12\% of all) in 2016. Since the analysis is based on proxy indicators; it requires more detailed data to explain the lack of small farms supported in 2014-2015, as well as the overall reduction in the supported farms in this period. 


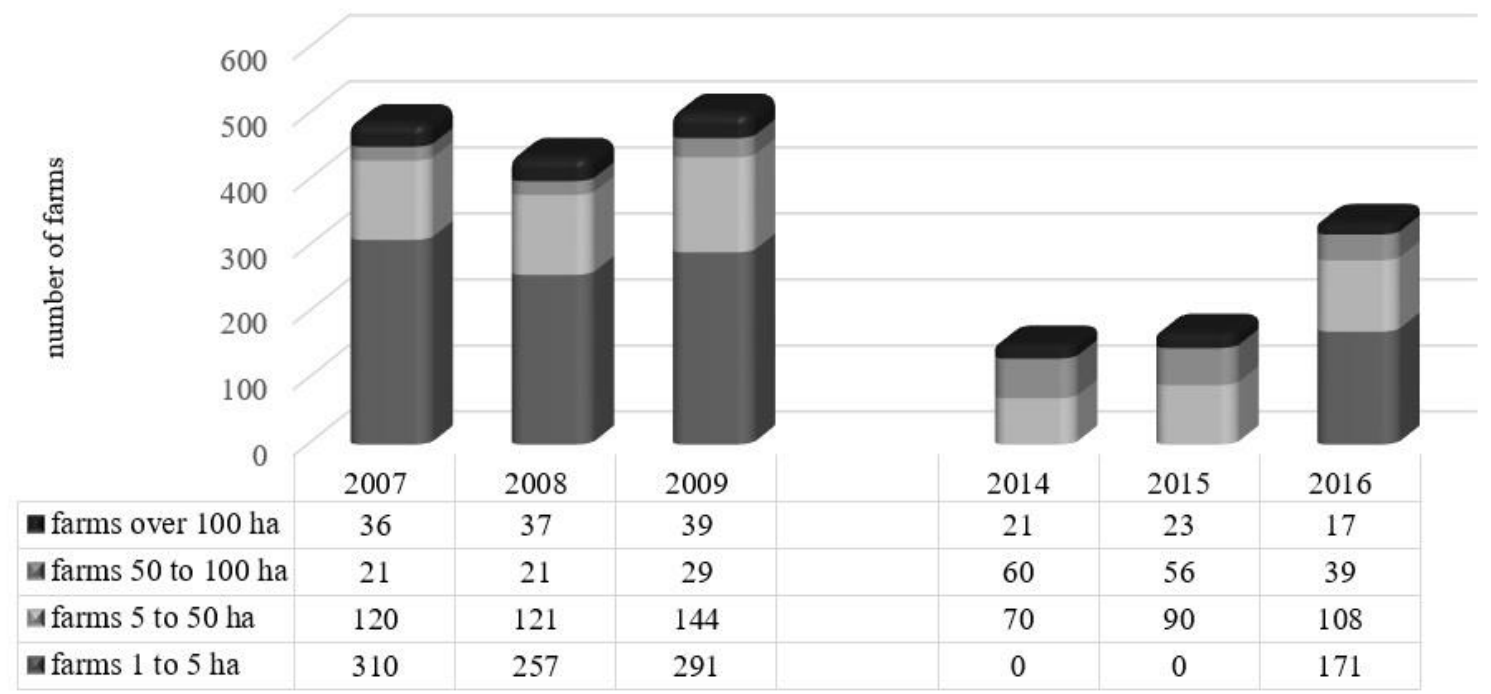

Figure 2. Beneficiaries of the measure on LFA (HP2) support in Plovdiv district

Source: Own calculations, based on State Fund Agriculture implementation data, published online.

\section{Achievement of the support objectives}

Four objectives for the support in areas with natural constraints are set in the national legal framework. Each of them is assessed individually:

1) Maintaining the agricultural activity in less favoured areas and preventing the abandonment of agricultural land

The agricultural activity and land use is assessed based on the land and its eligibility in the Land Parcel Identification System (LPIS), which is defined as agricultural land. The eligibility of the agriculture land in LPIS is used as a proxy indicator of land use intensity - the more eligible land, the more intensive the land use. The less eligible land, the less use of the agriculture land and the higher the threat by abandonment.

LPIS data is published since 2014; therefore, the data for 2014 and 2016 is used. Overall, the agricultural land in the areas with natural constraints in Plovdiv district increases from 2014 to 2016 - from 23716 ha to 24290 ha (Table 1). At the same time, the share of eligible land is maintained at $86.2 \%$ indicating no significant change in land use intensity in this period (not referring to the use of external inputs). The area of arable land and permanent pastures decreases slightly, while the area of permanent crops increases slightly. The biggest increase by over 800 ha is in the mixed land use. This can be explained by the region's favourable conditions for vegetables and fruits production as well as the increase in the organic production.
Arable land maintains very high land eligibility for support, while the other three categories permanent crops, permanent pastures and mixed land use, vary between $75 \%$ and $78 \%$.

The data indicates maintenance of the agriculture activity and prevention of land abandonment, but there is no certainty whether and to what extent is the contribution of the support under this measure.

\section{2) Counteract on the depopulation of less favoured areas}

This is the objective, which was taken out at EU level but introduced in Bulgaria in 2007, which makes it disputable. The official data reveals that for the 2007-2017 decade, the population in the 22 settlements with lands with natural constraints in Plovdiv district decreases by $6.7 \%$ (Table 2). The biggest decrease is in the settlements of Brezovo and Kaloyanovo municipalities (- 28.9\% and $28.1 \%$ ). At the same time, there are settlements with positive trends - in Asenovgrad municipality $(+7.4 \%)$ and in Stamboliiski municipality $(+5.9 \%)$. Overall, the population trends between the settlements in the different municipalities are too varied to be attributed to the support under this measure. This coincides with the findings of EU-level evaluation of the LFA measure (IEEP, 2006) which concludes "the original objective of seeking to prevent rural depopulation through the continuation of farming has ceased to be relevant in most parts of the EU-15 as the share of employment directly dependent on agriculture has declined". 
Table 1. Land use in the areas with natural constraints in Plovdiv district

\begin{tabular}{|c|c|c|c|c|c|c|}
\hline \multirow{3}{*}{ Land use } & \multicolumn{3}{|c|}{2014} & \multicolumn{3}{|c|}{2016} \\
\hline & $\begin{array}{c}\text { physical } \\
\text { blocks }\end{array}$ & eligible area & share & $\begin{array}{c}\text { physical } \\
\text { blocks }\end{array}$ & eligible area & share \\
\hline & (ha) & (ha) & $(\%)$ & (ha) & (ha) & $(\%)$ \\
\hline Arable land & 10639 & 10384 & 97.6 & 10543 & 10277 & 97.5 \\
\hline Permanent pastures & 4847 & 3668 & 75.7 & 4616 & 3498 & 75.8 \\
\hline Permanent crops & 2832 & 2143 & 75.7 & 2900 & 2268 & 78.2 \\
\hline Mixed landuse & 5398 & 4249 & 78.7 & 6231 & 4883 & 78.4 \\
\hline Total & 23716 & 20444 & 86.2 & 24290 & 20926 & 86.2 \\
\hline
\end{tabular}

Source: Ministry of Agriculture website, accessed 20 May 2017, own calculations

Table 2. Population in the areas with natural constraints in Plovdiv district, 2007-2013 and 20142017 periods

\begin{tabular}{|c|c|c|c|c|c|c|c|}
\hline \multirow{2}{*}{ Municipality } & \multirow{2}{*}{$\begin{array}{c}\text { Settlements } \\
\text { (LAU 2) } \\
\text { (number) }\end{array}$} & \multicolumn{5}{|c|}{ Population (number) } & \multirow{2}{*}{$\begin{array}{c}\text { change } \\
2017 / 2007 \\
(\%)\end{array}$} \\
\hline & & 2007 & 2010 & 2013 & 2014 & 2017 & \\
\hline Asenovgrad & 1 & 1508 & 1578 & 1604 & 1625 & 1619 & 7.4 \\
\hline Brezovo & 3 & 717 & 634 & 554 & 544 & 510 & -28.9 \\
\hline Kaloyanovo & 2 & 810 & 741 & 662 & 647 & 582 & -28.1 \\
\hline Karlovo & 7 & 3598 & 3494 & 3398 & 3349 & 3269 & -9.1 \\
\hline Maritsa & 1 & 684 & 681 & 670 & 669 & 683 & -0.1 \\
\hline Purvomai & 2 & 2417 & 2303 & 2259 & 2226 & 2148 & -11.1 \\
\hline Stamboliiski & 2 & 3996 & 4109 & 4141 & 4196 & 4233 & 5.9 \\
\hline Saedinenie & 1 & 376 & 352 & 329 & 323 & 302 & -19.7 \\
\hline Hisarya & 3 & 9640 & 9431 & 9121 & 8999 & 8801 & -8.7 \\
\hline Total & 22 & 23746 & 23323 & 22738 & 22578 & 22147 & -6.7 \\
\hline
\end{tabular}

Source: GRAO 2007, 2010, 2013, 2014, 2017 June; own calculations

3) Maintaining the landscape and biodiversity; and 4) Rational use, conservation and sustainable management of the land and other natural resources

The maintenance of landscape and biodiversity and the sustainable management of the land and other natural resources are assessed together as both of them aim at positive contribution to the environment.

The potential of areas with natural constraints is assessed based on their proximity to or overlap with Natura 2000 zones. Natura 2000 zones cover the areas with nature conservation importance at European level. The closer to Natura 2000 areas the higher potential to contribute to biodiversity conservation. The contribution to landscape maintenance is assessed based on the diversity of land uses in the region. The more dominant arable land use, the less diverse is the landscape.

The overlay of the areas with natural constraints and Natura 2000 zones in Plovdiv district reveal that there are 10 settlements which have lands in Natura 2000 zone and 12 settlements are outside them (Figure 3).

The land use diversity and contribution to landscape maintenance is assessed for the two groups of settlements - within and outside Natura 2000 zones (Table 3). The overall land use increases both in the settlements within and in outside Natura 2000 zones from 2014 to 2016. However, land eligibility increases in the settlements within Natura 2000 and reduces in the settlements outside them. This implies increased land use intensity in the Natura 2000 zones and reduced intensity outside them. 


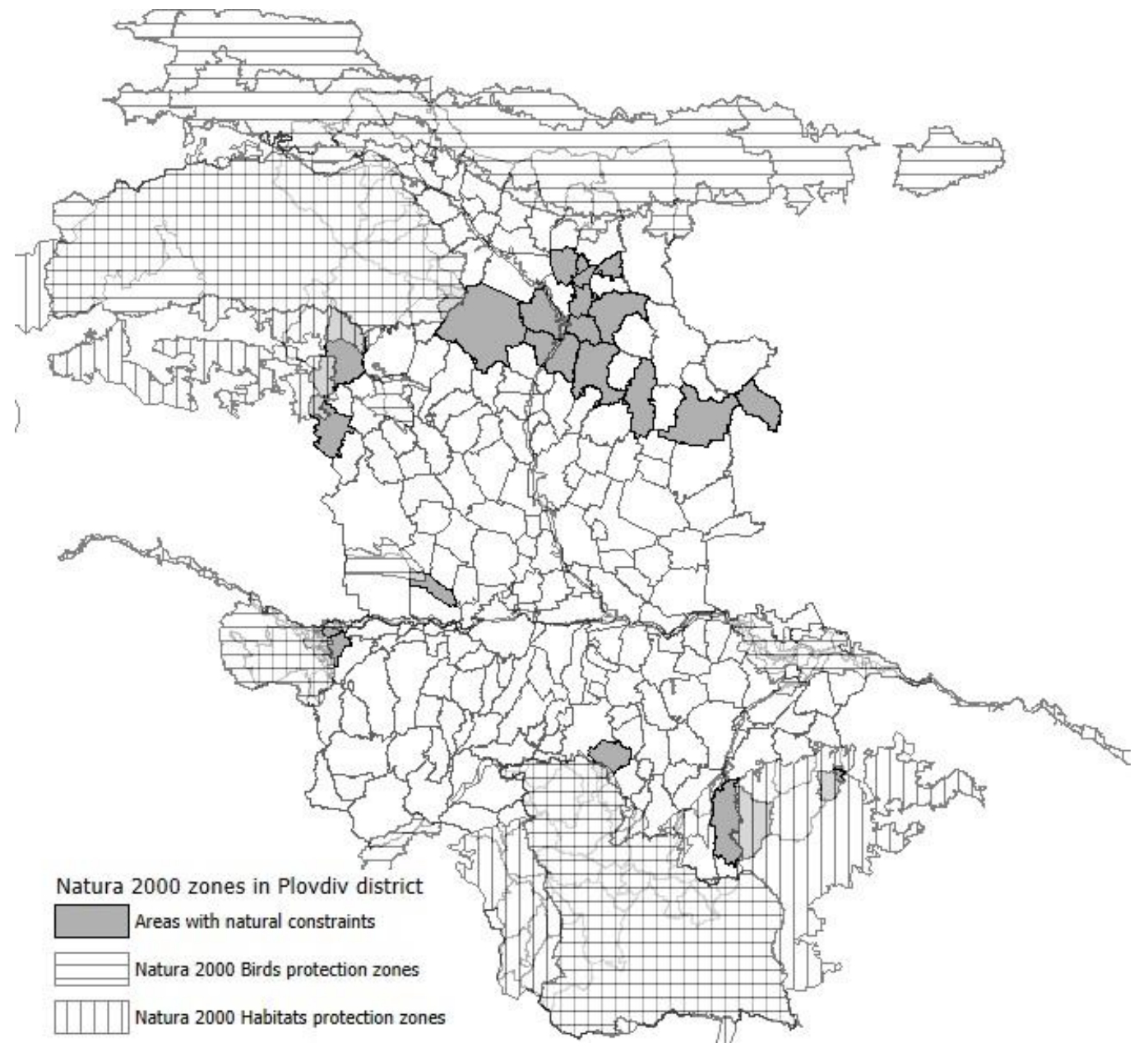

Figure 3. Areas with natural constraints and Natura 2000 zones in Plovdiv district

Source: own visualization based on Ministry of Environment GIS data on Natura 2000 zones.

Table 3. Land use and land eligibility for support in the settlements with natural constraints with and without Natura 2000 zones (hectares)

\begin{tabular}{|l|l|l|l|l|l|l|l|l|}
\hline \multirow{2}{*}{ Land use type } & \multicolumn{9}{|c|}{$\mathbf{2 0 1 4}$} & \multicolumn{3}{c|}{2016} \\
\cline { 2 - 5 } & $\begin{array}{l}\text { Land } \\
\text { in use }\end{array}$ & $\begin{array}{l}\text { Eligible } \\
\text { land }\end{array}$ & $\begin{array}{l}\text { Share of } \\
\text { ligible } \\
\text { land } \\
(\%)\end{array}$ & $\begin{array}{l}\text { Share of } \\
\text { landuse } \\
\text { in total } \\
(\%)\end{array}$ & $\begin{array}{l}\text { Land } \\
\text { in use }\end{array}$ & $\begin{array}{l}\text { Eligible } \\
\text { land }\end{array}$ & $\begin{array}{l}\text { Share of } \\
\text { eligible } \\
\text { land } \\
(\%)\end{array}$ & $\begin{array}{l}\text { Share of } \\
\text { landuse } \\
\text { in total } \\
(\%)\end{array}$ \\
\hline
\end{tabular}

Settlements in Natura 2000 zones (10 settlements in Plovdiv district)

\begin{tabular}{|l|l|l|l|l|l|l|l|l|}
\hline Arable land & 5886 & 5735 & 97.4 & 39 & 5926 & 5785 & 97.6 & 39 \\
\hline Permanent pastures & 3788 & 2833 & 74.8 & 25 & 3514 & 2670 & 76.0 & 23 \\
\hline Permanent crops & 1721 & 1393 & 80.9 & 11 & 1682 & 1359 & 80.8 & 11 \\
\hline Mixed landuse & 3746 & 3009 & 80.3 & 25 & 4247 & 3439 & 81.0 & 28 \\
\hline Total & $\mathbf{1 5 1 4 1}$ & $\mathbf{1 2 9 7 0}$ & $\mathbf{8 5 . 7}$ & $\mathbf{1 0 0}$ & $\mathbf{1 5 3 6 9}$ & $\mathbf{1 3 2 5 3}$ & $\mathbf{8 6 . 2}$ & $\mathbf{1 0 0}$ \\
\hline S60.
\end{tabular}

Settlements with natural constraints without Natura 2000 zones (12 settlements in Plovdiv district)

\begin{tabular}{|l|l|l|l|l|l|l|l|l|}
\hline Arable land & 4754 & 4650 & 97.8 & 55 & 4618 & 4450 & 96.4 & 52 \\
\hline Permanent pastures & 1060 & 835 & 78.8 & 12 & 1102 & 832 & 75.5 & 12 \\
\hline Permanent crops & 1111 & 750 & 67.5 & 13 & 1218 & 821 & 67.4 & 14 \\
\hline Mixed landuse & 1650 & 1240 & 75.2 & 19 & 1983 & 1571 & 79.2 & 22 \\
\hline Total & $\mathbf{8 5 7 5}$ & $\mathbf{7 4 7 5}$ & $\mathbf{8 7 . 2}$ & $\mathbf{1 0 0}$ & $\mathbf{8 9 2 1}$ & $\mathbf{7 6 7 4}$ & $\mathbf{8 6 . 0}$ & $\mathbf{1 0 0}$ \\
\hline
\end{tabular}

Source: Ministry of Agriculture website, accessed 20 May 2017, own calculations

The landscape variety is higher in the areas with natural constraints in Natura 2000 zones. In 2014, arable land covers $39 \%$, permanent pastures and mixed land use $25 \%$ each, and permanent crops $11 \%$. In 2016, the shares of arable land and permanent crops are 
maintained, but the permanent pastures decrease, while mixed land use increases. This can be an indication of permanent pastures conversion to arable land in small-scale use, the so-called mixed land use. This change, together with the increased eligibility in Natura 2000 areas, implies increased intensity of land use at the expense of permanent pastures. Overall, this puts a negative pressure on biodiversity, as permanent pastures are the agricultural habitat most directly linked to biodiversity conservation.

The landscape in areas with natural constraints outside Natura 2000 zones is dominated by arable land. In 2014, the arable land covers $55 \%$ of all agricultural land, the permanent pastures and permanent crops are $12 \%$ and $13 \%$ each, and mixed land use is $19 \%$. In 2016 , the share of arable land decreases to $52 \%$, and mixed land use increases to $22 \%$. The mixed land use has higher potential to contribute to diverse landscape. The increased share of eligible land for support in the mixed land use type from $75.2 \%$ in 2014 to $79.2 \%$ in 2016 indicates increased land use intensity.

The landscape variety and the land use intensity in the two groups of areas with natural constraints (within and outside Natura 2000 zones) differ. There is higher landscape diversity in Natura 2000 areas but also higher land use intensity. The presence of Natura 2000 zone can explain the landscape variety but one would also expect less intensive land use. In Plovdiv district, the data indicates more intensive land use; therefore, it is worth studying whether the same is valid for the areas with natural constraints in the other districts of the country. One explanation could be the additional payment that is provided to areas in Natura 2000 to compensate for the land use restrictions in the designation orders. If that is the case, what is the specific role of the payments for areas with natural constraints?

\section{CONCLUSION}

The support to areas with natural constraints was provided to farmers since 2007 . It has four main objectives, including a socio-economic one for addressing depopulation of rural areas. The data reveals that the main objective for maintaining agricultural activity is relevant in terms of agricultural land use. At the same time, the number of farmers who are supported under the measure decreases. Therefore, it is recommended to develop indicators to measure the agricultural activity in terms of land and economic agents (farms/people) dealing with it. The objective for addressing the depopulation of rural areas does not seem to be achieved with or without the support under the measure. In either case, it is recommended that this objective is better addressed with other instruments and is taken out of measure 13.2. The contribution to biodiversity and landscape maintenance requires further studies to distinguish between the contribution from this measure and the Natura 2000 compensatory payments in the areas with natural constraints overlapping with Natura 2000 zones.

Acknowledgments: This study is performed in the framework of project No.D002/9.12.2016 „Testing BIOdiversity Gain of European Agriculture with CAP greening - BIOGEA", implemented in the 2016-2019 period and funded by the Bulgarian National Scientic Fund (BNSF).

\section{REFERENCES}

1. Court of Auditors. Special Report No 4/2003 concerning rural development: support for less-favoured areas, together with the Commission's replies. 2003/C 151/01, C151, Volume 46, June 2003

2. EC Regulation 1698/20 September 2005 on support for rural development by the European Agricultural Fund for Rural Development (EAFRD)

3. EU Regulation 1305/17 December 2013 on support for rural development by the European Agricultural Fund for Rural Development (EAFRD) and repealing Council Regulation (EC) No.1698/2005

4. DG Agri. Fine-tuning in Areas facing Significant Natural and Specific Constraints. Working document, Brussels, July 2016

5. Ordinance for defining the criteria for lessfavoured areas and their territorial scope, adopted by Council of Ministers Decision No.30/15 February 2008

6. JRC. A. Hagyo, J.M. Terres, R. Koeble. ANCs criteria, Aggregation procedure and Soil data base issues. A presentation at workshop on Areas facing natural or other specific constraints, Brussels, 18 October 2016

7. Ordinance 11/3 April 2008 regulating the conditions and procedure for the implementation of measure 211 Support to farmers in mountainous areas and measure 212 Support to farmers in areas with handicaps different from mountain areas under the Rural Development Programme 2007-2013

8. Ordinance 6/24 February 2015 for the implementation of measure 13 Payments to areas with natural or other specific constraints under the Rural Development Programme 2014-2020

9. DG Agri. EU Agriculture Economic Briefs: What is a small farm?, Brief No.2, July 2011

10. IEEP. An Evaluation of the Less Favoured Area Measure in the 22 Member States of the European Union. A report prepared by the Institute for European Environmental Policy for DG Agriculture, London, 2006 
